\title{
An Empirical Study on the Influence of Media Attention on Real Earnings Management
}

\author{
Yang Meng ${ }^{1, *}$ \\ ${ }^{1}$ School of Economics and Management, Jiangsu University of Science \& Technology, Zhenjiang, Jiangsu 212003, \\ China \\ *Corresponding author. Email: 357992915@qq.com
}

\begin{abstract}
Based on the rapid development of social media in today's era, this paper take the data of Shenzhen Stock A manufacturing listed companies from 2013 to 2018 as samples, and examine the impact of media attention on the company's real earnings management through OLS regression analysis. This paper find that there is a significant positive correlation between the degree of real earnings management and media attention, that is, the higher the media attention is, the more the management can adopt real trading activities to manipulate earnings.
\end{abstract}

Keywords: social media, media attention, real earnings management, manufacturing

\section{INTRODUCTION}

Since the establishment of the capital market, financial fraud has been repeatedly prohibited, and a series of financial fraud cases have also had a huge social impact, damaging the interests of the majority of investors. The exposure of financial scandals makes earnings management become a hot topic in the theoretical and practical circles once again. Studies at home and abroad show that earnings management is universal and plays an important role in corporate value, corporate operations, corporate finance, etc. However, excessive earnings management has triggered behaviors such as profit manipulation and false information disclosure that have seriously impaired the healthy development of the capital market. Roychowdhury [1], Purwanti [2] and others point out that companies can control earnings not only through accruals but also through real activities. The diversification, concealment and complexity of earnings management methods have brought severe challenges to governance.

The development of media acts as an intermediary in many aspects of society, especially the rise of social media in recent years, making the spread of information faster and wider. Some studies hold the opposite view, believing that media coverage will greatly increase the pressure of the company in the capital market, leading the management to increase the degree of earnings manipulation to meet the market's expectation of earnings.

There are few studies on real earnings management. Most research on media attention generally only includes traditional media, but less research on emerging social media on earnings management. As a pillar industry in China, manufacturing has become one of the industries with the most serious problems in earnings management. During his visit to Henan, President xi said, "China must develop the real economy. Manufacturing is the important foundation of the real economy, and self-reliance is the basis of our efforts." This shows the important position of manufacturing industry in our country. To this end, this paper will take manufacturing companies as samples and add social media attention data on the basis of traditional media. This paper studies the effect of media attention on the real earnings management of listed manufacturing companies in China under the current social media environment, and then provides decision-making references for relevant stakeholders, regulatory authorities and company shareholders.

\section{THEORETICAL ANALYSIS AND RESEARCH HYPOTHESIS}

Earnings management is an important area of corporate governance, which plays an important role in balancing corporate profits and sustainable financing. Accrual earnings management is the behavior of the company's management authorities to achieve a specific purpose by choosing to use accounting policies and estimates, manipulating accrual items and so on to whitewash and change financial report information. Schipper [3] believes that real earnings management is an act of manipulating a company's earnings according to the expected target by arranging real business transactions, constructing actual business operations.

Media, as an important external governance body, is becoming more and more important in corporate governance. S Chahine [4] believes that media's meticulous reports on enterprises are often like dominoes to a certain extent, touching the earnings management field of enterprises. For media with a wide range of information sources, this domino effect will become more and more significant. Nicole L. Cade [5] believes that social media promotes two-way public communication -- between individuals, individuals and companies. lthough it is impossible to control others' opinions on a company 
through social media, it can help managers to understand the needs of the public more comprehensively and extensively.

Most scholars believe that there are mainly "efficient supervision hypothesis" and "market pressure hypothesis" in media attention affecting earnings management behavior of companies. Media has increasingly become an important external supervision mechanism, which can alleviate the degree of information asymmetry in the market, thus effectively inhibiting the earnings management behavior of listed companies. The theory of "effective supervision hypothesis" holds that the higher the attention of media, the more supervision and governance effect it can have on listed companies, and the lower the degree of earnings management of companies will be. At the same time, the attention of the media will also create strong market pressure on the performance of the management. When the company's operating performance cannot be changed in a short period of time, the management tends to adopt various earnings management methods to achieve market expectations. Therefore, the "market pressure hypothesis" believes that the higher the media attention, the higher the degree of earnings management of listed companies.

In recent years, with the perfection of law and accounting system, only relying on accruals for earnings management can no longer meet the company's needs. Y Chen [6] believes that the media's active supervision role through its reputation mechanism can effectively restrain the earnings management of enterprises. However, under great market pressure, the management tends to adopt various means of earnings management to achieve market expectations, so as to avoid the situation of negative earnings [7]. Cohen et al. [8] argued that media attention would increase the pressure on management and the motivation for earnings management would increase. However, the media attention makes earnings management easier to find, so even though the real earnings management will bring negative economic consequences to the enterprise, the management still prefers this kind of earnings management. Compared with accrual earnings management, real active earnings management is difficult to attract the attention of stakeholders. Moreover, the penalty cost of adopting accrual earnings management is higher, so some companies will adopt real earnings management. That is, media attention may increase the degree of real earnings management of listed companies. In view of the above analysis, hypothesis $\mathrm{H} 1$ is also proposed in this chapter:

H1: media attention is positively correlated with the real earnings management behavior of listed companies. That is, the increase of media attention to some extent promotes the real earnings management behavior of the management of listed companies.

\section{RESEARCH DESIGN}

\subsection{Sample Selection and Data Sources}

This article selects the listed companies of the Shenzhen Stock Exchange from 2013 to 2018 as a sample. Among the listed companies in China, manufacturing companies are a very important group. In this paper, the main object of research is listed manufacturing companies. In this way, the research will be more targeted and the accuracy will be improved accordingly. On this basis, we excluded the samples of ST and PT. Then we excluded the samples with abnormal and missing data and the newly listed companies in that year. Finaly, we conducted tail reduction processing on the continuous variable of $1 \%$. After preliminary processing, a total of 8195 samples were collected.

The financial data in this article are mainly from the CSMAR database. The media report data comes from the financial news database(CFND) and social media database (CSMD) of listed companies in the Chinese Research Data Services (CNRDS). For data collation, this paper adopts the mode of "database + manual collation". For data processing and analysis, the software used in this paper is Excel and STATA 15.0.

\subsection{Variable Definitions}

Definition 1. (real earnings management, AREM) In view of the lack of research on real earnings management by domestic scholars, this paper draws on Roychowdhury's research method. The net cash flow from abnormal operating activities (EM_CFO) was used to measure sales control. Abnormal discretionary expense (EM_DISX) was used to measure discretionary expense control, and abnormal product cost (EM_PROD) was used to measure production control. EM_CFO, EM_DISX and EM_PROD are calculated from the actual value of the year minus the estimated normal value. The absolute value of the total amount of real earnings management (AREM) is used to measure the degree of real active earnings management.

Operating cash flow model. There is a linear relationship between the company's normal operating cash flow and sales income, as shown in model (1) :

$\frac{C F O_{\mathrm{j}, \mathrm{t}}}{T A_{j, t-1}}=\beta_{0}\left[\frac{1}{T A_{j, t-1}}\right]+\beta_{1}\left[\frac{S A L E S_{j, t}}{T A_{j, t-1}}\right]+\beta_{2}\left[\frac{\Delta S A L E S_{j, t}}{T A_{j, t-1}}\right]+\varepsilon_{j, t}$ $T A_{j, t-1}$ is the total assets at the end of the period; $\triangle S A L E S_{j, t}$ is the change of main business income; $C F O_{\mathrm{j}, \mathrm{t}}$ is net cash flow from operating activities, $S A L E S_{j, t}$ is operating income. The abnormal cash flow from operating activities is obtained by subtracting the expected cash flow from operating activities from the actual cash flow from operating activities of the company.

Production cost model. The production cost is equal to the sum of the cost of products sold and inventory changes. The 
normal production cost and sales revenue of the company have a linear relationship as shown in model (2) :

$\frac{P R O D_{j, t}}{T A_{j, t-1}}=\beta_{0}\left[\frac{1}{T A_{j, t-1}}\right]+\beta_{1}\left[\frac{\text { SALES }_{j, t}}{T A_{j, t-1}}\right]+\beta_{2}\left[\frac{\Delta \text { SALES }_{j, t}}{T A_{j, t-1}}\right]+\beta_{3}\left[\frac{\Delta S A L E S_{j, t-1}}{T A_{j, t-1}}\right]+\varepsilon_{j, t}$

$P R O D_{\mathrm{j}, \mathrm{t}}$ is the production cost of the company, and

$\triangle S A L E S_{j, t-1}$ is the change of sales revenue. Take the company's actual production cost and subtract the expected production cost to get the company's abnormal production cost EM_PROD.

Discretionary cost model. Discretionary expenses include sales expenses and administrative expenses, and there is a linear relationship between the company's normal discretionary expenses and sales revenue as shown in model (3) :

$$
\frac{D I S X_{\mathrm{j}, \mathrm{t}}}{T A_{j, t-1}}=\beta_{0}\left[\frac{1}{T A_{j, t-1}}\right]+\beta_{1}\left[\frac{S A L E S_{j, t-1}}{T A_{j, t-1}}\right]+\varepsilon_{j, t}
$$

$D I S X_{\mathrm{j}, \mathrm{t}}$ is discretionary expense and $S A L E S_{j, t-1}$ is the company's sales revenue. The abnormal discretionary expenses of the company are obtained by subtracting the expected discretionary expenses from the actual discretionary expenses of the company.

Real activity total earnings management model. The total amount of real earnings management shall be equal to abnormal production costs minus cash flows from abnormal operating activities and abnormal discretionary expenses, as shown in model (4) :

$$
R E M_{j, t}=E M_{-} P R O D_{j, t}-E M_{-} C F O_{j, t}-E M_{-} D I S X_{j, t} \text { (4) }
$$

Definition 2. (media attention, Media) In order to make media data comprehensive, this paper collects reports from newspaper media, Internet media and social media. The natural $\log$ of total media coverage +1 is used to represent media attention.

Definition 3. (company size, Size) The more assets an enterprise holds, the more capable it is of earnings management. In this paper, the natural logarithm of the total assets of an enterprise is used to reflect the size of the company.

Definition 4. (asset-liability ratio, Lev) There are differences in the influence of asset-liability ratio on earnings management, so this paper takes asset-liability ratio as one of the control variables.

Definition 5. (ownership concentration, Con) The degree of equity concentration has an impact on earnings management. This paper uses the shareholding ratio of the largest shareholder to measure the degree of equity concentration.

Definition 6. (return on assets, ROA) The return on assets affects the management's earnings manipulation to some extent, so the asset-liability ratio is taken as one of the control variables in this paper.

Definition 7. (company growth, Grow) In this paper, the growth rate of the operating income of the current year relative to the operating income of the previous year represents the growth of the company.

\subsection{Model Building}

In order to verify the impact of media attention on real earnings management, the following model was constructed: $\operatorname{AREM}_{i, t}=\alpha_{0}+\alpha_{1}$ Media $_{i, t}+\sum \alpha_{i}$ Control $_{i, t}+\sum$ Year $+\varepsilon_{i, t}$

\section{THE EMPIRICAL ANALYSIS}

\subsection{Descriptive Statistics}

In this paper, after sorting out the data of the major variables related to the a-share manufacturing listed companies in Shenzhen stock exchange, 8195 valid samples were finally obtained. Meanwhile, Stata15.0 was used for descriptive statistical analysis of the major variables, including mean, standard deviation, median, minimum and maximum. Table 1 shows the descriptive statistical analysis of the main related variables for five consecutive years from 2013 to 2018, as shown below.

According to the data in table 1, it can be found that the maximum value of AREM is 1.719 , the minimum value is 0 , and the standard deviation is 0.126 . The mean value of AREM is 0.126 and the median value is 0.089 , indicating that most of the selected sample enterprises have conducted real active earnings management. It can be explained that real earnings management is common in listed manufacturing companies in China, and its manipulation degree is also relatively serious.

The average value of explanatory variable Media is 6.265 and the median value is 6.409 , indicating that Chinese listed manufacturing companies generally receive Media attention. The maximum value of Media is 9.341, and the minimum value is 2.773. There are large differences among enterprises, which are related to the unbalanced development of China's capital market and the tendency of Media reports.

In addition to year, there are altogether 5 control variables in this paper. The specific analysis are as follows:

The mean value of Size is 22.116, the median value is 21.981 , the maximum value is 25.693 , the minimum value is 19.940 , and the standard deviation is 1.116 . It can be seen that there is little difference in the size of sample companies as a whole.

The mean value of Lev was 0.396 and the median value was 0.386 , which was within a reasonable range. Moreover, compared with other industries, the balance sheet level of manufacturing companies was not high. The maximum value is 0.852 , and the minimum value is 0.048 . The difference between the two is large, indicating that there is still a big difference between the asset and liability levels of different companies.

The average value of ROA is 0.041 , indicating that the return on assets of listed manufacturing companies in China is generally low and their profitability needs to be improved. The minimum value is -0.293 , the maximum value is 0.212 , and the standard deviation is 0.052 , indicating that there are 
significant differences in the profitability of listed manufacturing companies in China, which need to be transformed.

Table 1 Descriptive Statistics

\begin{tabular}{|c|c|c|c|c|c|c|}
\hline Variable & $\mathrm{N}$ & mean & $\mathrm{sd}$ & $\min$ & $\mathrm{p} 50$ & $\max$ \\
\hline AREM & 8195 & 0.126 & 0.126 & 0.000 & 0.089 & 1.719 \\
\hline Media & 8195 & 6.265 & 1.493 & 2.773 & 6.409 & 9.341 \\
\hline Size & 8195 & 22.116 & 1.116 & 19.940 & 21.981 & 25.693 \\
\hline Lev & 8195 & 0.396 & 0.187 & 0.048 & 0.386 & 0.852 \\
\hline Con & 8195 & 0.337 & 0.137 & 0.088 & 0.319 & 0.750 \\
\hline ROA & 8195 & 0.041 & 0.052 & -0.293 & 0.035 & 0.212 \\
\hline Grow & 8195 & 0.184 & 0.369 & -0.511 & 0.121 & 2.537 \\
\hline
\end{tabular}

The Con value is between 0.088 and 0.750 , with a mean value of 0.337 and a standard deviation of 0.137 , indicating that there is a large difference in the shareholding ratio of the largest shareholder in listed manufacturing companies in China. Moreover, since the current definition of holding authority in the international academic community is that the shareholding ratio of the controlling shareholders of the company is between $20 \%$ and $25 \%$ [9], it can be seen that most enterprises still have a high degree of ownership concentration. It shows that although China's capital market has been developing and improving, the high degree of equity concentration has not been effectively solved.

The minimum value of Grow is - 0.511 , the maximum value is 2.537 , the mean value is 0.184 , and the standard deviation is 0.369 , indicating that there are differences in the development speed of companies, which requires listed

Table 2 Pearson correlation analysis manufacturing companies in China to adjust their structure reasonably.

\subsection{Correlation Analysis}

In this paper, Pearson correlation analysis was conducted for each variable to preliminarily test the correlation among variables. Table 2 is the Pearson correlation analysis table for each variable.

Through the correlation test between independent variables and dependent variables, it can be seen that Media and AREM are significantly positively correlated, which preliminarily indicates that Media attention can promote the company's real earnings management manipulation.

\begin{tabular}{|c|c|c|c|c|c|c|c|}
\hline & AREM & Media & Size & Lev & Con & ROA & Growth \\
\hline AREM & 1.000 & & & & & & \\
\hline Media & $0.044^{\star \star \star}$ & 1.000 & & & & & \\
\hline Size & -0.002 & $0.271^{\star * *}$ & 1.000 & & & & \\
\hline Lev & $-0.023^{\star *}$ & $0.124^{\star \star \star}$ & $0.510^{\star * \star}$ & 1.000 & & & \\
\hline Con & $0.019^{*}$ & $0.048^{\star * *}$ & $0.148^{\star * *}$ & $0.027^{\star *}$ & 1.000 & & \\
\hline $\mathrm{ROA}$ & $0.255^{\star \star \star}$ & $0.082^{\star \star \star}$ & $0.022^{\star \star}$ & $-0.344^{\star \star \star}$ & $0.127^{\star \star \star}$ & 1.000 & \\
\hline Grow & $0.163^{\star \star \star}$ & 0.007 & $0.040^{* * *}$ & $0.034^{\star * \star}$ & -0.017 & $0.192^{* \star *}$ & 1.000 \\
\hline
\end{tabular}

The correlation test between control variables and dependent variables shows that ROA, Con and Grow are significantly positively correlated with AREM. Lev was negatively correlated with AREM. Size is negatively correlated with AREM, but not significantly. This is only a preliminary judgment, and more accurate results depend on multiple linear regression analysis.

\subsection{Multiple Regression Analysis}

As can be seen from the regression results in table 3 , the correlation coefficient between media attention and the degree of real earnings management is 0.007 and significantly positive at the level of $1 \%$. The hypothesis $\mathrm{H} 1$ proposed in this paper has been verified. This shows that the higher the media attention the listed manufacturing companies receive, the more likely they are to adopt real earnings management. 
The regression coefficient of Lev and AREM is 0.085, which is significantly positively correlated at the level of $1 \%$, indicating that the higher the asset-liability ratio is, the more likely the enterprise is to conduct real earnings management. ROA is significantly positively correlated

\section{REFERENCES}

[1] Sugata Roychowdhury. Earnings management through real activities manipulation[J]. Journal of Accounting and Economics,2006,42(3). DOI: https://doi.org/10.2139/ssrn.477941

[2] Dyah Purwanti. Real Activities Manipulation (RAM) and Accrual-based Earning Management Pre and Post IFRS Adoption in Indonesia[P]. Proceedings of the 2016 Global Conference on Business, Management and Entrepreneurship,2016.

DOI:

https://doi.org/10.2991/gcbme-16.2016.16

[3] Schipper K. Commentary on Earnings Management[J]. Accounting Horizons, 1989, 3(4):91102.

[4] Chahine S, Mansi S, Mazboudi M. Media news and Earnings Management Prior to Equity Offerings. Journal of Corporate Finance, 2015(35). DOI: https://doi.org/10.2139/ssrn.2658635

[5] Nicole L. Cade. Corporate social media: How twoway disclosure channels influence investors[J]. Accounting, Organizations and Society,2018. DOI: https://doi.org/10.2139/ssrn.2619249

[6] Chen Y, Cheng C S A, Li S, et al. The Monitoring Role of the Media: Evidence from Earnings Management. Social Science Electronic Publishing, 2017. DOI: https://doi.org/10.2139/ssrn.2938955

[7] Fang L, Peress J. Media coverage and the crosssection of stock returns $[\mathrm{J}]$. The Journal of Finance. 2009,64(5):2023-2052.

DOI:

https://doi.org/10.2469/dig.v40.n1.66

[8] Cohen, Zarowin. Accrual based and real earnings management activities around seasoned equity offerings $[\mathrm{J}]$. Journal of Accounting and Economics, 2010(50):2-19.

DOI:

https://doi.org/10.2139/ssrn.1081939

[9] Ruoyao Yuan. A study on the effect of internal control effectiveness on executive overemployment consumption from the perspective of media supervision [D]. Xi 'an university of technology,2019. 
[10] Cohen D.A, A. Dey, Thomas Z. L. Real and Accrual-Based Earnings Management in the Pre and Post-Sarbanes-Oxley Periods[J]. The Accounting Review, 2008, 83(3):757-787. DOI:

https://doi.org/10.2139/ssrn.813088 